\title{
Prevalence of Demodex spp. in students and employees of the Pomeranian Medical University in Szczecin*
}

\author{
Częstość występowania Demodex spp. u studentów i pracowników \\ Pomorskiego Uniwersytetu Medycznego w Szczecinie*
}

\author{
Katarzyna Dołęgowska ${ }^{凶}$ \\ Pomorski Uniwersytet Medyczny w Szczecinie, Zakład Diagnostyki Laboratoryjnej, al. Powstańców Wlkp. 72, 70-111 Szczecin \\ Pomeranian Medical University in Szczecin, Department of Laboratory Diagnostics \\ $\triangle$ kasia.dolegowska@gmail.com
}

\begin{abstract}
Introduction: Demodex folliculorum and Demodex brevis are mites living in the hair follicles and sebaceous glands of humans, with infestation usually being asymptomatic.

In the present study the prevalence and number of mites, together with influencing factors of Demodex infestation, were investigated in students and personnel of the Pomeranian Medical University in Szczecin in Poland (PUM). The prevalence of 2 Demodex species, Demodex folliculorum and Demodex brevis, was compared in epilated eyelashes and skin scrapings derived from healthy volunteers.

Materials and methods: The study was conducted on 217 healthy volunteers - females and males. The study group consisted of 114 students and 103 employees of PUM. From each study participant, 2-3 eyelashes from each lid were epilated. From 99 volunteers, skin scrapings and/or secretions from sebaceous glands were also obtained. Demodicosis was diagnosed when Demodex eggs, larvae or adult mites were identified under microscopic examination.
\end{abstract}

Results: The infestation rate of Demodex (in epilated eyelashes and skin) among the 217 volunteers was $21 \%$. Prevalence of hair follicle mites among personnel and students were $28 \%$ and $14 \%$ respectively. The mean number of mites among the 217 patients was $2.52 \pm 2.48$ (3.16 \pm 2.9 in PUM personnel and $1.46 \pm 0.83$ in students). The infestation rate increased with age $(p=0.0005)$. Demodex folliculorum infested $78 \%(\mathrm{p}=0.005)$ of the participants and $87.5 \%$ of epilated eyelashes $(\mathrm{p}=0.000001)$. Demodex brevis was more frequent on the skin $(67 \% ; p=0.00001)$. Hair follicle mites were detected more often in epilated eyelashes originating from the lower lid ( $p=0.000001)$. Moreover, a weak correlation between the presence of selected symptoms (blepharedema, conjunctivitis, burning and itching of eyelids) and Demodex infestation was observed. There was no statistically significant association between Demodex infestation and an influencing factor: work using a microscope $(\mathrm{p}=0.92)$.

Keywords: Demodex mite; demodicosis; Demodex folliculorum; Demodex brevis.

\begin{abstract}
ABSTRAKT
Wstęp: Nużeńce Demodex folliculorum i Demodex brevis są roztoczami występującymi w mieszkach włosowych i gruczołach łojowych ludzi. Zarażenie nużeńcem może przebiegać bezobjawowo. Celem przeprowadzonych badań była ocena ekstensywności zarażenia Demodex spp. w rzęsach i skórze twarzy u studentów i pracowników Pomorskiego Uniwersytetu Medycznego w Szczecinie (PUM).

Materiały i metody: Badania przeprowadzono u 217 zdrowych ochotników - kobiet i mężczyzn - podzielonych na 2 grupy: 114 studentów i 103 pracowników. Od każdej osoby uczestniczącej w badaniu pobierano po 2-3 rzęsy z górnej i dolnej powieki obu oczu. Od 99 osób pobrano również zeskrobiny skóry i/lub wydzielinę gruczołów łojowych twarzy. Wynik dodatni badania przyjmowano na podstawie stwierdzenia obecności postaci rozwojowych Demodex folliculorum i Demodex brevis - jaj, larw lub postaci dojrzałych. Wyniki: Obecność Demodex spp. w rzęsach i/lub skórze twarzy stwierdzono u 21\% badanych. Wśród pracowników odsetek osób
\end{abstract}

zarażonych Demodex spp. wynosił 28\%, natomiast w grupie studentów $14 \%$. Ekstensywność zarażenia Demodex spp. wzrasta wraz z wiekiem $(\mathrm{p}=0,0005)$. Odsetek osób zarażonych $D$. folliculorum (rzęsy i/lub skóra twarzy) wyniósł $78 \%(\mathrm{p}=0,005)$, w przypadku infestacji samych rzęs - 87,5\% ( $\mathrm{p}=0,000001)$. W skórze częściej stwierdzano obecność $D$. brevis $(67 \%$; $\mathrm{p}=0,00001)$. W rzęsach średnia liczba osobników Demodex spp. wyniosła 2,52 $\pm 2,48$, w tym u pracowników 3,16 $\pm 2,9$, a u studentów $1,46 \pm 0,83(p=0,03)$. U osób zarażonych stwierdzono częstsze występowanie Demodex spp. na rzęsach powiek dolnych niż górnych $(\mathrm{p}=0,000001)$. Wykazano słabą korelację pomiędzy występowaniem niektórych objawów (obrzęk powiek, zapalenie spojówek, świąd i pieczenie powiek) a zarażeniem Demodex spp. Nie wykazano związku między pracą z mikroskopem a zarażeniem nużeńcem $(\mathrm{p}=0,92)$.

Słowa kluczowe: nużeniec; demodekoza; Demodex folliculorum; Demodex brevis.

\footnotetext{
* Based on the Master's thesis accepted by the Council of the Faculty of Medicine and Biotechnology and Laboratory Medicine of the Pomeranian Medical University in Szczecin. Promoter: dr hab. n. med. Lidia Kołodziejczyk. The original includes 63 pages, 20 figures, 6 photographs, 14 tables and 103 references.
} 


\section{INTRODUCTION}

Demodex spp. are external obligatory parasites found in hair follicles and sebaceous glands of mammalian skin. Two species Demodex folliculorum and Demodex brevis - occur in humans [1]. In a study to determine the extensiveness of Demodex spp. it has been observed that most people are infested with this parasite [2]. Although the presence of Demodex spp. may be associated with numerous skin pathologies, they are also commonly detected in healthy individuals [3].

The symptoms accompanying demodicosis are slight redness and dryness of the skin, as well as conjunctivitis, dysfunction of Meibomian glands, and dry eye syndrome [4, 5 , $6,7]$. Demodex folliculorum occur in clusters near the roots of eyelashes and hair follicles, whereas D. brevis usually occurs singly in sebaceous glands and Meibomian glands [8]. In men, the symptoms of infestation are more frequent than in women, probably due to the more abundant production of sebum. Demodex folliculorum is more likely to cause infestations, but $D$. brevis occurs over a larger area of the body [9]. Demodex spp. is rare in children and teenagers; it is believed that neonates may become infested with nebulae shortly after birth by direct contact, but their density remains low due to low sebum production in the first years of life $[10,11]$.

Demodex spp. probably plays an important role in the development and course of various dermatological diseases, such as follicular dandruff, perioral dermatitis, eyelid dermatitis, rosacea, rosacea-like rash, pustulosis and granulomatous dermatitis [12].

\section{MATERIALS AND METHODS}

The study was conducted on 217 healthy volunteers - women and men, divided into 2 groups: 114 students and 103 employees of the Pomeranian Medical University in Szczecin (PUM). In a research, 2-3 eyelashes were aseptically collected with tweezers from the upper and lower eyelids of both eyes from each person. They were placed between a slide and a cover slip and viewed under a light microscope (magnifications 100x, 400x). A positive result was obtained on the basis of the presence of developmental forms: eggs, larvae or mature forms of D. folliculorum and/or D. brevis.

Scrapings of the face skin (using a sharp spoon) and/or sebaceous gland secretion were also collected for diagnostic tests from 99 of the subjects. The tested material was placed on a slide, covered with $10 \%$ potassium hydroxide (KOH) and a cover slip. The preparation was viewed under a light microscope (magnifications 100× 400×). Infestation was diagnosed when eggs, larvae or mature forms of $D$. folliculorum and/or D. brevis were observed.

\section{RESULTS}

Among the 217 participants, $21 \%$ (45) were infested with Demodex spp. Their presence was found on eyelashes and/or in the skin of the face. In the group of students, the infestation rate was $14 \%$, while among the employees it was twice as high (28\%). A statistically significant correlation was found between the infestation rate and age ( $p=0.0005)$ - Figure 1 .

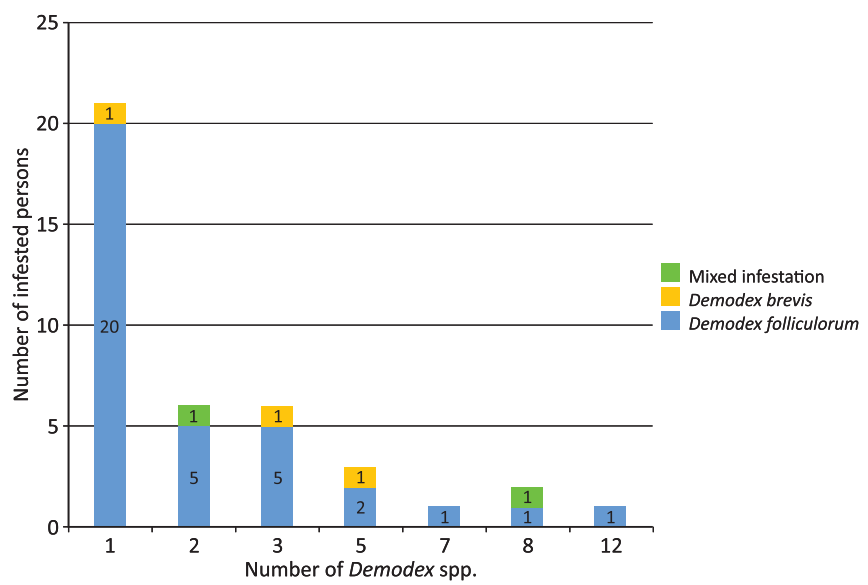

FIGURE 1. Number of Demodex spp. detected in infested persons, by species

The presence of $D$. folliculorum was more frequent in all infested subjects $(78 \%)$ than D. brevis $(11 \% ; \mathrm{p}=0.005)$. Demodex folliculorum dominated in the eyelashes $(\mathrm{p}=0.000001)$, whereas $D$. brevis dominated in skin scrapings and/or sebaceous secretions $(\mathrm{p}=0.00001)$. During examination of the eyelashes, Demodex spp. were more frequent in the material collected from the lower eyelids than from the upper eyelids ( $p=0.000001)$ - Figures 2 and 3 .

Out of 217 participants, 164 declared symptoms that could potentially indicate the occurrence of ocular or dermal demodicosis. These symptoms included itching and burning of the eyelids, swelling of the eyelids, tearing of the eyes, loss of eyelashes, conjunctivitis, festering inflammation of the eye, skin

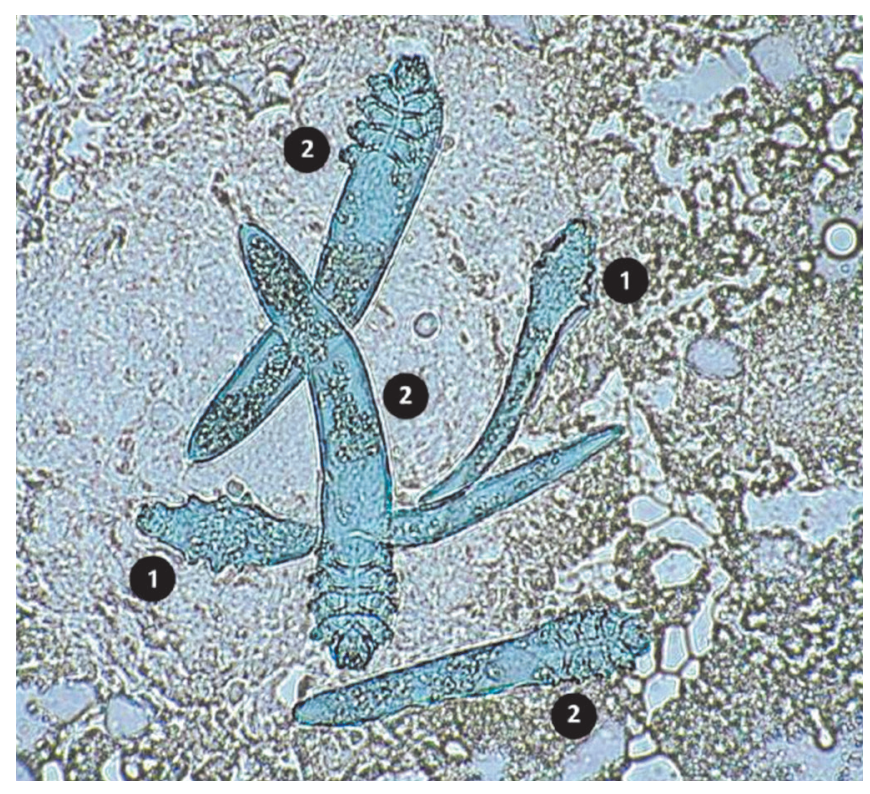

FIGURE 2. Larvae (1) and adult Demodex folliculorum (2) in facial sebaceous secretions (100× magnification) 


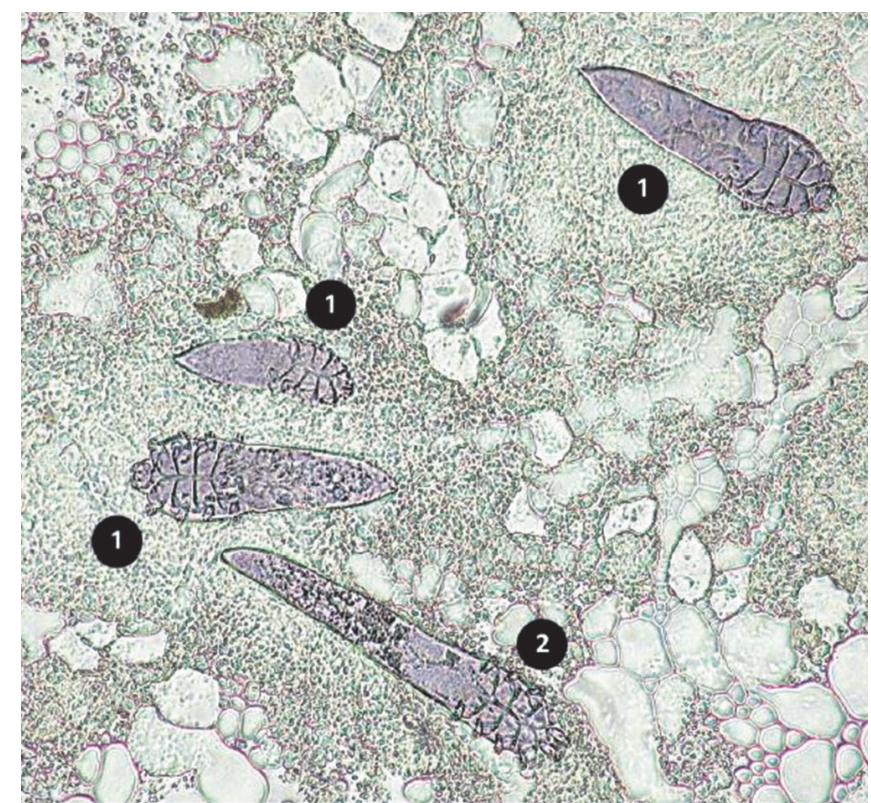

FIGURE 3. Mixed infestation in sebaceous secretions of the facial skin glands with adult Demodex brevis (1) and Demodex folliculorum (2) 100× magnification

lesions (comedo) and itching of the skin around the forehead, mouth, nostrils and chin. A positive result of parasitological examination for Demodex spp. was found in 32 subjects (20\%) declaring symptoms and 13 subjects (25\%) not reporting any symptoms of demodicosis. No significant correlation was demonstrated between the demodicosis symptoms reported by the patients (at least one mentioned in the survey) and Demodex spp. infestation $(\mathrm{p}=0.43)$.

Out of the 217 participants, 153 people worked with a microscope. In this group the percentage of people infested with Demodex spp. was $21 \%$ (32 persons), and in the group of people without any contact with a microscope the infestation rate was $20 \%$ ( 13 persons). There was no significant correlation between working with the microscope and Demodex spp. infestation $(p=0.92)$.

\section{DISCUSSION AND CONCLUSIONS}

Demodex folliculorum mites and D. brevis are common human parasites $[2,13,14,15,16,17]$. Their prevalence increases with age, and in people over 70 may reach even $100 \%[18,19,20]$. In this study, Demodex spp. was found in $21 \%$ of subjects, where among university employees it was higher (28\%) than among students (14\%).

In sociodemographic studies on healthy populations conducted in China $[21,22,23,24,25,26,27,28,29,30]$ and Turkey [31, $32,33]$, the proportion of infested persons among primary, secondary and tertiary level students ranged $21.3-37.7 \%$. Another study in China on students aged 18-22 years reported an exceptionally high prevalence (92.8\%) of Demodex spp. infestation of the skin [29]. According to those researchers, that elevated rate was related to the multiple repetition of tests which increased the reliability of diagnosis [34,35]. Such a high percentage of infested young people may also be due to the type of Demodex spp. detection method commonly used in China - cellophane tape method (CTP). It consists of sticking several cellophane tapes to the face at night, then observing them under a light microscope the next morning. According to Zhao et al. [29], this method is the best for studying the extensiveness of Demodex spp. infestation in a healthy population and is more sensitive than other commonly used methods because of the movement of Demodex spp. at night to the mouth of the hair follicle for mating.

In studies conducted in patients with various facial skin diseases, skin biopsy and standard skin surface biopsy (SSSB) are recommended methods for detecting Demodex spp. Skin biopsy allows an observation of the damage caused by the pathological process in the histological fragment of the deeper skin layers. However, the invasiveness of this method requires the use of local anesthesia. In contrast, a standard skin surface biopsy is an easy and fast method that detects Demodex spp. in the follicle infundibulum and determines Demodex spp. density per $1 \mathrm{~cm}^{2}$ of skin. In SSSB, cyanoacrylate is placed on the surface of the microscope slides, which is applied to the test person's skin for $1 \mathrm{~min}$, and then detached and viewed under a stereomicroscope. The cellophane tape method, similar to surface skin biopsy, uses cellophane and cyanoacrylate. Standard skin surface biopsy is actually even a more sensitive method than CTP [29, 36]. Forton and De Maertelaer [37] attempted to increase the sensitivity of SSSB and performed 2 biopsies immediately after each other in the same place, after cleaning the slide and skin with ether. The obtained results were comparable to the detection of Demodex spp. by confocal microscope. The second superficial skin biopsy enabled the examination of deeper skin layers and the collection of about twice as many individuals [37].

In this study, D. folliculorum (78\%) was the most frequently detected Demodex spp. species on eyelashes. Infestations caused by $D$. brevis or co-infestations were less frequent. These results confirm numerous reports $[21,22,23,27,28,29,31,38$, 39] which indicate that $D$. folliculorum is the dominant Demodex spp. species on humans. More frequent detection of $D$. folliculorum may also be associated with the exact location of both species within the hair follicles. Demodex folliculorum occurs in the follicle infundibulum near its exit, whereas D. brevis occurs deeper, in the sebaceous glands [40].

In this research, D. brevis was a more frequently detected species (67\%) on the skin. This was probably due to the type of method used to detect Demodex spp. on the skin. Demodex spp. were found mainly in sebaceous gland secretions (78\%) and less frequently in skin scrapings (22\%). This assumption is confirmed by research conducted by Akilov and Mumcuoglu [41], who, using the same method, obtained a higher prevalence of D. brevis infestation (41\%). In a study in which a standard skin surface biopsy was performed, the main species detected was D. folliculorum, most likely due to the small amount of sebaceous secretions collected by that method [42].

This study did not show any correlation between Demodex spp. infestation and the presence of skin/eye demodicosis 
symptoms. Similar results were obtained by Isa et al. [31] and Seyhan et al. [40], in contrast to earlier studies [43, 44], which showed a statistically significant correlation between these symptoms and infestation with Demodex spp. These discrepancies may be due to the fact that many factors (e.g. environmental, hormonal, individual) may cause similar symptoms to those caused by the presence of Demodex spp. The results may also be influenced by differences between the detection methods. In Poland, they are usually qualitative methods based on the examination of eyelashes, skin scrapings or sebaceous gland secretions. Cellophane tape method and SSSB are quantitative methods whose aim is to determine the number of individuals per $1 \mathrm{~cm}^{2}$ of skin. In a superficial skin biopsy, demodicosis is confirmed by a concentration of $>5$ individuals per $1 \mathrm{~cm}^{2}$ of skin and $>10$ individuals during the second SSSB, with symptoms suggesting Demodex spp. infestation [29, 37, 45, 46]. However, so far, there has been no clear indication of the minimum number of individuals responsible for the symptoms caused by the Demodex spp. infestation [8].

There was weak correlations between the occurrence of some symptoms of ocular demodicosis, such as eyelid swelling, conjunctivitis, itching and burning of eyelids, and the identification of Demodex spp. on the eyelashes. The research conducted among PUM employees also showed that the microscope as a working tool did not constitute a transmission factor for Demodex spp. On one hand, this may be due to the limited life expectancy of these mites outside the human body and the need for direct contact during transmission [8]. Garbacewicz et al. [47] demonstrated, however, in their study on a group working with the microscope on a daily basis, that the percentage of infested persons is similar to that found in the control group, whose mean age was 20 years higher. Due to the fact that the infestation rate among people working with a microscope was higher than their age might indicate, the microscope was indirectly considered as one of the transmission factors in that study.

Problems with maintaining eyelash hygiene result in a favorable environment for the spread and development of this parasite. However, the lack of specific symptoms of ocular demodicosis and the need for eyelash epilation to assess the infestation makes diagnostics problematic [48]. Detection of Demodex spp. is not very likely during random eyelash epilation. However, the detection of Demodex spp. on eyelashes accompanied by cylindrical dandruff increases the possibility of detection [7]. A study by Randon et al. [48] using in vivo confocal microscopes (IVCM) showed the reliability and effectiveness for the detection of ocular demodicosis. It also allows the evaluation of Meibomian glands and increases the possibility of detecting $D$. brevis larvae and adult individuals $[48,49]$.

\section{SUMMARY}

The effects of Demodex spp. infestations on human health are not fully understood. Studies carried out to determine the extensiveness of the occurrence of Demodex spp. show that most people are infested with these parasites [2]. However, in most cases their presence does not cause any symptoms. The pathological role of Demodex spp. in humans is still a subject of numerous discussions and controversies. There is increasing evidence that they may become an opportunistic pathogen in conditions conducive to development and proliferation [50]. It is believed that one of the factors responsible for the transformation from clinically asymptomatic colonization of mites to dermatitis is primary or secondary immuno-suppression. Therefore, symptomatic infestation with $D$. folliculorum mites can be expected more often in immunocompromised patients, e.g. in AIDS, hematopoietic proliferative disease, and during immunosuppressive therapy (also topically) [12].

A recent study has implicated bacteria isolated from Demodex spp. mites in diseases such as rosacea or eyelid inflammation [51]. Further research to determine the role of Demodex spp. in skin and eyelid diseases and to improve the detection rate of these mites will help in designing new effective treatments.

\section{REFERENCES}

1. Lacey N, Ní Raghallaigh S, Powell FC. Demodex Mites - commensals, parasites or mutualistic organisms? Dermatology 2011;222(2):128-30.

2. Desch CE. Human hair follicle mites and forensic acarology. Exp Appl Acarol 2009;49(1-2):143-6.

3. Lacey N, Kavanagh K, Tseng SCG. Under the lash: Demodex mites in human diseases. Biochem (Lond) 2009;31(4):2-6.

4. Rather PA, Hassan I. Human demodex mite: the versatile mite of dermatological importance. Indian J Dermatol 2014;59(1):60-6.

5. Chen W, Plewig G. Human demodicosis: revisit and a proposed classification. Br J Dermatol 2014;170(6):1219-25.

6. Gao YY, Di Pascuale MA, Elizondo A, Tseng SC. Clinical treatment of ocular demodecosis by lid scrub with tea tree oil. Cornea 2007;26(2):136-43.

7. Hom MM, Mastrota KM, Schachter SE. Demodex. Optom Vis Sci 2013;90(7):198-205.

8. Cheng AM, Sheha H, Tseng SC. Recent advances on ocular Demodex infestation. Curr Opin Ophthalmol 2015;26(4):295-300.

9. Aylesworth R, Vance JC. Demodex folliculorum and Demodex brevis in cutaneous biopsies. J Am Acad Dermatol 1982;7(5):583-9.

10. Baima B, Sticherling M. Demodicidosis revisited. Acta Derm Venereol 2002;82(1):3-6.

11. Kaya S, Selimoglu MA, Kaya OA, Ozgen U. Prevalence of Demodex folliculorum and Demodex brevis in childhood malnutrition and malignancy. Pediatr Int 2013;55(1):85-9.

12. Kulac M, Ciftci IH, Karaca S, Cetinkaya Z. Clinical importance of Demodex folliculorum in patients receiving phototherapy. Int J Dermatol 2008;47(1):72-7.

13. Bikowski JB, Del Rosso JQ. Demodex dermatitis: a retrospective analysis of clinical diagnosis and successful treatment with topical crotamiton. J Clin Aesthet Dermatol 2009;2(1):20-5.

14. Dhingra KK, Saroha V, Gupta P, Khurana N. Demodex-associated dermatologic conditions - a coincidence or an etiological correlate. Review with a report of rare case of sebaceous adenoma. Pathol Res Pract 2009;205(6):423-6.

15. Forton F, Germaux MA, Brasseur T, De Liever A, Laporte M, Mathys C, et al. Demodicosis and rosacea: epidemiology and significance in daily dermatologic practice. J Am Acad Dermatol 2005;52(1):74-87.

16. Lee SH, Chun YS, Kim JH, Kim ES, Kim JC. The relationship between demodex and ocular discomfort. Invest Ophthalmol Vis Sci 2010;51(6):2906-11.

17. Zaleska-Żmijewska A, Garbacewicz A, Udziela M, Twarowska J, Grytner-Zięcina B, Szaflik J. Przewlekłe zapalenia brzegów powiek a zarażenie roztoczami z rodzaju Demodex. Alergia 2010;2:28-31. 
18. Czepita D, Kuźna-Grygiel W, Czepita M, Grobelny A. Demodex folliculorum and Demodex brevis as a cause of chronic marginal blepharitis. Ann Acad Med Stetin 2007;53(1):63-7.

19. Czepita D, Kuźna-Grygiel W, Kosik-Bogacka D. Nużeniec jako czynnik etiologiczny przewlekłego zapalenia powiek. Klin Ocz 2005;107:10-2.

20. Liu J, Sheha H, Tseng SC. Pathogenic role of Demodex mites in blepharitis. Curr Opin Allergy Clin Immunol 2010;10(5):505-10.

21. Cao YS, You QX, Wang L, Lan XB, Xu J, Zhang XH, et al. Facial Demodex infestation among college students in Tangsham. Chin J Parasitic Dis Contr 2009;27(3):271-3.

22. Chen XY, Shen HX, Li XM, Lin WY, Li GP, Ruan YF, et al. The investigation of human follicle mite infection in college students. J Trop Med 2004;4(4):401-3.

23. Di BH, Li X, Li CY. Investigation of human follicle mite infection in Tianjin college student. Chin J Health Lab Technol 2007;17(7):1279-313.

24. Hong Y, Yu XF, Li D, He TT, Wang YN, Zhu M, et al. Investigation on the Demodex in students from Xinjiang Medical College. Endemic Dis Bulletin 2009;24(2):13-5.

25. Jiang TC, Li YL, Peng W. Mite infections among college students in Yichang. J Shanxi Med Univ 2002;33(S1):5-6.

26. Peng FL, Wang XL, Cao HX. Demodex facial infection in students at Yichun College and its association with seborrheic dermatitis. J Yichun Coll 2009;31(2):85-6.

27. Tian XL. Survey of facial Demodex infection among medical college students with oily skin. China Tropical Med 2011;2:190-1.

28. Wang HY, Wang XX, Tu LX. Infection of human Demodex on facial skin of middle and primary students in rural areas of Huaibei. Mod Prev Med 2010;37(9):1728-9.

29. Zhao Y, Guo N, Xun M, Xu J, Wang M, Wang D. Sociodemographic charakcteristics and risk factor analysis of Demodex infestation (Acari: Demodicidae). J Zhejiang Univ Sci B 2011;12(12):998-1007.

30. Zhou M, Zhou DS, Dong JC, Luo YD, Liu WT, Zhou RH. Investigation on the Demodex infection among 2475 students of middle and primary school. Chin J Parasit Dis Con 2004;17(4):243-4.

31. Isa NHM, Loong LW, Fang GH, Mohamad AM, Razali N, Rani NI, et al. Demodicosis among university medical students in Malaysia and the effects of facial cleanser and moisturizer usage. Southeast Asian J Trop Med Public Health 2011;42(6):1375-80.

32. Kaplan M, Keleştemur N, Başpinar S. Demodex spp. Prevalence among university students. Kafkas Univ Vet Fak Derg 2012;18(Suppl-A):A43-A46.

33. Okyay P, Ertabaklar H, Savk E, Erfug S. Prevalence of Demodex folliculorum in young adults: relation with sociodemographic/hygienic factors and acne vulgaris. J Eur Acad Dermatol Venereol 2006;20 (4):474-5.

34. Wang GY. Investigation of relation between detection rate and examination times of Demodex infestation. Acad J Kaifeng Med Coll 2000;19(3):10.

35. Zhao YE, Xun M, Guo N, Huang CJ. Investigation of epidemiology and pathology of Demodex mite. Shaanzi Med J 2006;35(11):1416-28.
36. Klingman AM, Christensen MS. Demodex folliculorum: requirements for understanding its role in human skin disease. J Invest Dermatol 2011;131(1):8-10.

37. Forton FM, De Maertelaer V. Two consecutive standardized skin surface biopsies: an improved sampling method to evaluate demodex density as a diagnostic tool for rosacea and demodicosis. Acta Derm Venereol 2017;97(2):242-8.

38. Kuźna-Grygiel W, Kosik-Bogacka D, Czepita D. Demodex folliculorum i Demodex brevis w etiologii zapalenia brzegów powiek. Sympozjum: Parazytozy - Problemy Kliniczne; Białystok; 2003, p. 28-31.

39. Zhao YE, Peng Y, Wang XL, Wu LP, Wang M, Yan HL. Facial dermatosis associated with Demodex: a case-control study. J Zhejiang Univ Sci B 2011;12(12):1008-15.

40. Seyhan ME, Karincaoğlu Y, Bayram N, Aycan Ö, Kuku I. Density of Demodex folliculorum in heamatological malingnancies. J Int Med Res 2004;32(4):411-5.

41. Akilov OE, Mumcuoglu KY. Immune response in demodicosis. J Eur Acad Dermatol Venereol 2004;18(4):440-4.

42. Erbağci Z, Özgöztaşi O. The significance of Demodex folliculorum density in rosacea. Int J Dermatol 1998;37(6):421-5.

43. Hu Q, Wang Y. Investigation on the prevalence of human Demodex among 2,248 medical students in inner Mongolia. Zhongguo Ji Sheng Chong Xue Yu Ji Sheng Chong Bing Za Zhi 2001;19(4):239-40.

44. Ljuboevæ S, Basta-Juzbasiæ A, Lipozenéiæ J. Steroid dermatitis resembling rosacea: aetiopathogenesis and treatment. J Eur Acad Dermatol Venereol 2002;16(2):121-6

45. Așkin Ü, Seçkin D. Comparison of the two techniques for measurement of the density of Demodex folliculorum: standardized skin surface biopsy and direct microscopic examination. Br J Dermatol 2010;162(5):1124-6.

46. Forton F, Seys B, Marchal JL, Song AM. Demodex folliculorum and topical treatment: acaricidal action evaluated by standardized skin surface biopsy. Br J Dermatol 1998;138(3):461-6.

47. Garbacewicz A, Udziela M, Grytner-Zięcina B, Szaflik JP, Szaflik J. Zakażenie nużeńcem w populacji ludzkiej - u chorych na zapalenie brzegów powiek i osób w grupie ryzyka, jakie stwarza praca z mikroskopem. Klin Ocz 2010;10-12:307.

48. Randon M, Liang H, El Hamdaoui M, Tahiri R, Batellier L, Denoyer A, et al. In vivo confocal microscopy as a novel and reliable tool for the diagnosis of Demodex eyelid infestation. Br J Ophthalmol 2015;99(3): 336-41.

49. Margalit A, Kowalczyk MJ, Żaba R, Kavanagh K. The role of altered cutaneous immune responses in the induction and persistence of rosacea. J Dermatol Sci 2016;82(1):3-8.

50. Layton A, Thiboutot D. Emerging therapies in rosacea. J Am Acad Dermatol 2013;69(6 Suppl 1):S57-65.

51. McMahon F, Banville N, Bergin DA, Smedman C, Paulie S, Reeves E, et al. Activation of neutrophils via IP3 pathway following exposure to Demodexassociated bacterial proteins. Inflammation 2016;39(1):425-33. 